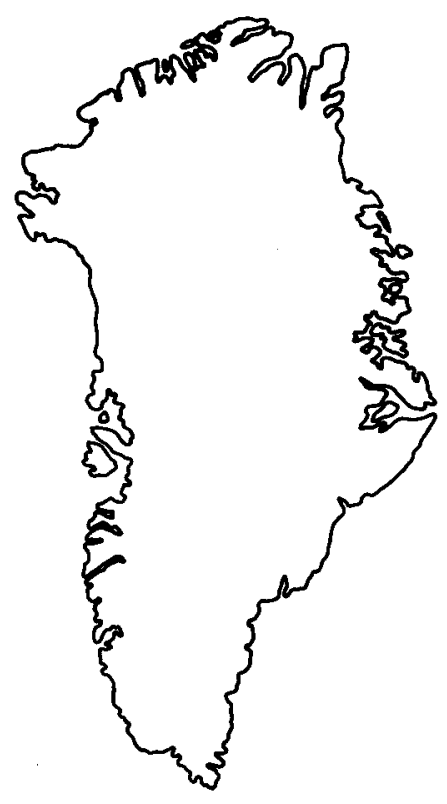

\title{
Giant Mollusca (Hyolitha) from the Permian of East Greenland
}

\author{
John S. Peel and Ellis L. Yochelson
}

Elongate, narrowly conical fossils from the Permian of Kap Stosch, northern East Greenland, are referred to the genus Macrotheca, previously known only from Pakistan and Timor. The specimens, and similar problematic molluscs from the Soviet Union previously referred to an extinct Class Xenoconchia, are interpreted as unusually large members of the extinct Class Hyolitha.

J.S.P., Grønlands Geologiske Undersøgelse, Øster Voldgade 10, DK-1350 København K, Danmark.

E.L.Y., U.S. Geological Survey, E-501, U.S. National Museum of Natural History, Washington D.C. 20560, U.S.A.

In $1958 \mathrm{~S}$. Bendix-Almgreen, Geologisk Museum, Copenhagen, collected several specimens of a large problematic invertebrate from the Permian of Kap Stosch, northern East Greenland $\left(74^{\circ} \mathrm{N}, 21^{\circ} \mathrm{W}\right)$. The fossils are simple cones closed at the apex and lack any internal septae. Ornamentation is limited to faint growth lines. The cross-section is nearly circular, slightly flattened on the presumed venter. The shell wall is as much as $5 \mathrm{~mm}$ thick and contains remnants of stacked nacre, an indication of molluscan affinities ( $R$. L. Batten, written communication, 1980). The most striking attribute of these fossils is their great size. The largest of the specimens from Kap Stosch is $40 \mathrm{~cm}$ long (fig. 1A). However, the aperture is broken so that the original length was certainly somewhat greater. This fossil is one of the largest invertebrates ever reported from the Permian.

The specimens from Kap Stosch are assigned to Macrotheca, Waagen, 1880, a genus first described from a large incomplete fragment, without apex, from the Salt Range of Pakistan (Waagen, 1880). Another specimen, in which the apex has been preserved, has also been described from Timor (Wanner, 1941). Both these records, together with the much better preserved material from Greenland, are from strata of Permian age.

Macrotheca was originally described as a member of the Class Hyolitha, although the scarcity and incompleteness of material have caused later authors to question the status of the genus (Fischer, 1962). The Greenland specimens permit a better understanding of Macrotheca and suggest that it is indeed a hyolith, albeit an unusual one.

Hyolitha is reasonably well established as an extinct class of the Mollusca (Marek \& Yochelson, 1976), although some authors consider hyoliths to be an extinct phylum (Runnegar et al., 1975; Runnegar, 1980). Conventional hyoliths are most abundant in the Cambrian and relatively scarce in younger strata. Specimens are commonly 1 to $2 \mathrm{~cm}$ long, 


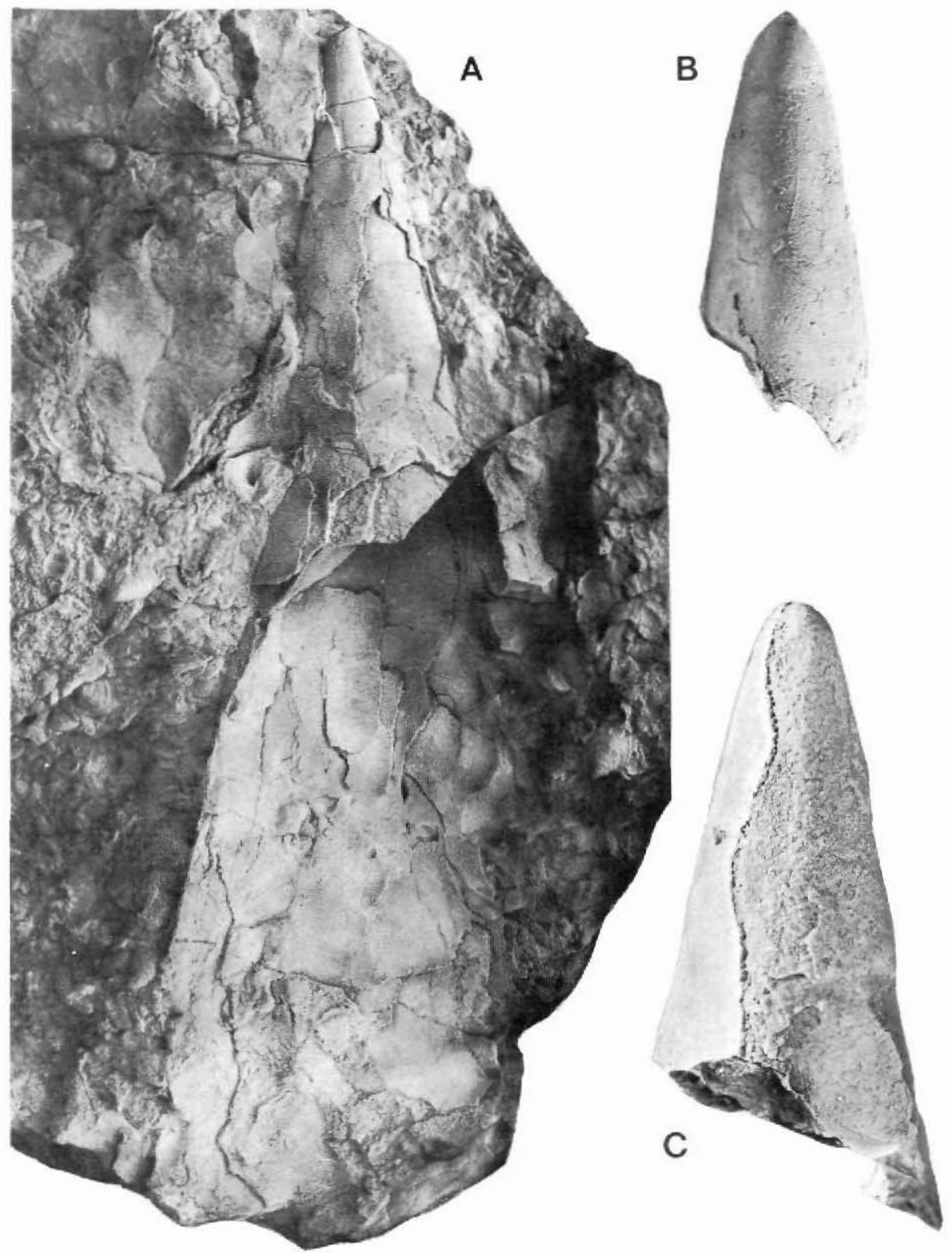

Fig. 1. Permian xenoconchs from Greenland and the U.S.S.R. A, C. Macrotheca sp., Permian of Kap Stosch, northern East Greenland. A, MGUH 15084 from GGU sample 29652, × 0.33. The apex and aperture are broken and parts of the shell have been stripped away; the lower half of the specimen has been crushed flat. C, MGUH 15085 from GGU sample 29652, × 1. Lateral view of the apex. (MGUH numbers denote the type collection of the Geological Museum, Copenhagen). B, Pseudotoxeuma magnifica Shimanskiy, Permian of the southern Ural Mountains, U.S.S.R. Specimen no. 1992/3 in the collections of the Palaeontological Institute, Moscow, $\times 1.5$. Plaster cast of the holotype in lateral view. 
although examples as much as one third the length of the Greenland individuals are known (Fischer, 1962). In common with Macrotheca, hyoliths have a closed apex and a slowly expanding, gently curved, conical shell. The cross-section of older hyoliths ranges from sub-triangular to circular and the exterior may be fluted, keeled or smooth.

The specimens of Macrotheca from East Greenland also permit a new insight into the Xenoconchia since their early growth stages are very similar to those specimens from the late Palaeozoic of the Ural Mountains upon which Shimanskiy (1963) based this extinct class (fig. $1 \mathrm{~B}, \mathrm{C}$ ). Indeed, Macrotheca can be assigned to the xenoconchs with some confidence.

Shimanskiy considered that the xenoconchs were possibly distant relatives of the gastropods. He also postulated that the shell might have been dorsal, although this interpretation cannot readily be reconciled with the narrowness of the shell relative to its length or with the great size of the shell. A sedentary mode of life, with the shell lying approximately flat on the sea floor is more plausible. This life style is in accordance with that commonly accepted for Hyolitha sensu stricto.

As noted by Shimanskiy (1963), it would appear that the xenoconchs, including Macrotheca, are probably molluscs. However, the strong affinity of the new material from East Greenland with the Hyolitha suggests that the xenoconchs should not be recognised as a separate class. It is probably preferable to transfer the xenoconchs to the Hyolitha as a taxon of ordinal rank, although this step must await full description of the Greenland material.

\section{References}

Fischer, D. 1962: Small conoidal shells of uncertain affinities. In Moore, R. C. (edit.) Treatise on Invertebrate Paleontology, W, Miscellanea, 98-143. Kansas U.P.

Marek, L. \& Yochelson, E. L. 1976: Aspects of the biology of Hyolitha (Mollusca). Lethaia 9, 65-82.

Runnegar, B. 1980: Hyolitha: status of the phylum. Lethaia 13, 21-25.

Runnegar, B., Pojeta, J., Jr., Morris, N. J., Taylor, J. D., Taylor, M. E. \& McClung, G. 1975: Biology of the Hyolitha. Lethaia 8, 181-191.

Shimanskiy, V. N. 1963: Systematic position and scope of Xenoconchia. Paleont. Zhur. 1963 (4), 53-63 (in Russian).

Waagen, W. H. 1880: Salt Range fossils. Part 2, Pisces and Gastropods. Mem. geol. Survey India 13, 73-183.

Wanner, C. 1941: Ein neuer Hyolithide aus dem Perm von Timor. Zentralbl. Mineral. Geol. Paläont. B, 1941, 92-95. 